Tasharruf: Journal Economics and Business of Islam Vol. 6, No. 1 (2021):1-19

Website: http://journal.iain-manado.ac.id/index.php/TJEBI/index

ISSN 2528-0325 (online) ISSN 2528-0317 (print)

\title{
ZAKAT AS A SOLUTION FOR PUBLIC ECONOMIC RECOVERY IN THE ERA OF COVID 19
}

\author{
Chadijah Haris \\ IAIN Manado, Manado \\ chadijah.haris@iain-manado.ac.id
}

\begin{abstract}
This article aims to describe the economic situation in the covid 19 pandemic era and analyze the function of zakat in restoring the society economy during the Covid-19 pandemic. The method used in this research was literature study. The data collection techniques were carried out in two ways comprised primary and secondary data. The data analysis was content analysis. The results showed that zakat served as a manifestation of human solidarity, which means that the rich are required to spend some of their wealth in the form of zakat, and distribute it to the needy, in this context how to see zakat function as a way to help economic recovery during the pandemic. So it can be concluded that with the distribution of zakat, such as Zakat Fitrah, Zakat Maal and professional Zakat, it can strengthen the solidarity and foster the relationship between human by helping the needs of people affected by Covid-19 and reduce the poverty during the pandemic that currently affect all people in the world, especially in Indonesia.
\end{abstract}

Keywords: Zakat; Economy; Poverty; Covid 19.

\begin{abstract}
ABSTRAK
Artikel ini bertujuan untuk menggambarkan situasi ekonomi pada era pandemi covid 19 dan menganalisis fungsi zakat dalam memulihkan ekonomi masyarakat pada masa pandemi covid-19. Metode yang digunakan dalam penelitian ini adalah studi pustaka. Teknik pengumpulan data dilakukan dengan dua cara yaitu primer dan sekunder, dan analisis data menggunakan analisis konten. Hasil penelitian menunjukkan bahwa zakat berfungsi sebagai perwujudan ikatan solidaritas sesama manusia, artinya yang kaya diwajibkan untuk mengeluarkan sebagian harta yang dimilikinya dalam bentuk zakat, dan dibagikan kepada mereka yang membutuhkan, dalam konteks ini bagaimana melihat zakat dapat berlaku sebagai salah satu cara yang dilakukan untuk membantu pemulihan ekonomi masyarakat di masa pandemi. Sehingga dapat disimpulkan bahwa dengan adanya penyaluran zakat, baik Zakat Fitrah, Zakat Maal dan Zakat profesi dapat terjalin hubungan tolong-menolong dan mengasihi sesama manusia dengan memenuhi kebutuhan masyarakat yang terdampak Covid 19 dan menekan angka kemiskinan dimasa pandemi yang saat ini melanda seluruh masyarakat di Dunia terutama di Indonesia.
\end{abstract}

Kata Kunci: Zakat; Ekonomi; Kemiskinan; Covid 19. 


\section{Tasharruf: Journal Economics and Business of Islam Vol. 6, No. 1 (2021):1-19 Website: http://journal.iain-manado.ac.id/index.php/TJEBI/index ISSN 2528-0325 (online) ISSN 2528-0317 (print)}

\section{INTRODUCTION}

The current pandemic has caused public panic all over the world (Kadir et al., 2020). The World Health Organization (WHO) declared the Covid 19 pandemic status on March 11, 2020, as a global pandemic because this virus has spread to several countries in the world. Several credible research institutions in the world predict the impact of Covid 19 on the global economy. The minister of Finance, Sri Mulyani Indrawati predicted the economic growth in Indonesia in the worst case scenario could reach to less $0.4 \%$ (Azwar, 2020). By this condition, the poverty rate in Indonesia will continue to increase and can suppress economic conditions and provide social impacts, especially poverty. Indonesia as a country that has the largest Muslim population in the world, provides solutions that are offered in the form or model of Islamic philanthropy (Iskandar \& Aqbar, 2020).

Islamic philanthropy is a foundation for the development of the social and economic power of the ummah which has several complex aspects. If these aspects can be actualized, community development will be achieved. (S. Hasan, 2007). The scope of Islamic philanthropy can be seen from the benefits or wisdom contained in it. These benefits include the spiritual aspect, videlicet by increasing belief in Allah SWT. The social aspect, the creation of community solidarity, which cause to emerge cherish and concern for others. and from the economic aspect is to create a safe, just and prosperous society. By the implementation of Islamic philanthropy, a prosperous, peaceful and prosperous society is created. One of the appropriate solutions for poverty alleviation is to promote social and economic activities by distributing Zakat.

Zakat is a solution for economic recovery during a pandemic. Several solutions are provided, such as direct cash assistance from Zakat obtained from zakat collection units (Baznas and Lazis), or directly from the community. Zakat institutions must keep their trust and commitment to promote social and economic welfare. Therefore, zakat institutions must update the strategies and programs they manage. Zakat which is the best alternative for the welfare of society in the era of Covid 19 and its implementation is based on zakat, infaq and shadaqah.

During this pandemic, the Amil Zakat Agency and the Amil Zakat Institution must be able to overcome the economic problems of the community, especially the lower class. Zakat is devoted to eight groups, but in the Covid-19 pandemic situation, it has an impact on many things. One of the economic sectors affected by the Covid-19 pandemic is the management of zakat by zakat institutions. The reason is that the income of muzakki has decreased which has 


\section{Tasharruf: Journal Economics and Business of Islam Vol. 6, No. 1 (2021):1-19 \\ Website: http://journal.iain-manado.ac.id/index.php/TJEBI/index ISSN 2528-0325 (online) ISSN 2528-0317 (print)}

an impact on the collection of zakat. In addition, the Covid-19 pandemic has caused an increase in the number of zakat recipients. To overcome this, zakat institutions can take several strategic steps in collecting and distributing zakat. In terms of zakat collection, zakat institutions can encourage muzakki to issue zakat at the beginning, so that they can immediately get zakat benefits during the Covid-19 pandemic. Meanwhile, in terms of distribution, zakat institutions can also distribute zakat to mustahik who are in dire need during a pandemic such as the poor.

Zakat funds can be allocated to treat victims affected by Covid-19 (Kadir et al., 2020). It is necessary to inform concerning the importance of Zakat so that the problem of poverty in the Covid-19 period can be resolved shortly (Rizal \& Mukaromah, 2021). By the various virtues of zakat in overcoming economic problems in the Covid-19 period, this is the reason for the importance of zakat and is the discussion in this study.

\section{RESEARCH METHOD}

This research uses the library research method. The process of collecting library data is divided into two types of data, namely primary and secondary. Primary data is the result of research on theses, scientific writings, and journals that have been published (Atabik, 2015; Ezziti, 2020; Hanoatubun, 2020; Kadir et al., 2020; Rizal \& Mukaromah, 2021), while secondary data comes from books, textbooks, and others. Data collection is done by reviewing various sources, both primary and secondary. The analysis technique used is content analysis. This analysis is carried out to find valid inferences so that they can be re-examined. In this analysis process, coding, comparative, and data reduction processes are carried out from various sources (Moleong, 2007).

\section{RESULT AND DISCUSSION}

\section{Covid-19: Poverty and The World Pandemic}

COVID-19 has become the biggest challenge in the world, not only threatening human life, but also It has a huge impact on the economy, security and religious customs. The situation is getting worse due to the lack of accurate guidance for dealing with emergencies (Bashir et al., 2021). Looking at Morgan's analysis of the world economy in 2020 minus $1.1 \%$ in 2020, the EIU predicts minus 2.2 percent and looks at Fitch's opinion that the world economy is minus 1.9 percent, and the IMF predicts the world economy is minus 3 percent. Sri Mulyani Indrawati from the Republic of Indonesia predicts the worst economic growth will reach negative $0.4 \%$ (Baldwin \& Weder, 2020). The World Bank's analysis shows that the economic impact of 


\section{Tasharruf: Journal Economics and Business of Islam Vol. 6, No. 1 (2021):1-19 Website: http://journal.iain-manado.ac.id/index.php/TJEBI/index ISSN 2528-0325 (online) ISSN 2528-0317 (print)}

Covid-19 will stop the business of nearly 24 million people in East Asia and the Pacific. In the worst-case scenario, the World Bank also predicts that nearly 35 million people will be in poverty. In fact, taking into account the various conditions of various poverty lines, the World Bank predicts the number of people living in extreme poverty worldwide will increase to 922 million (Bank, 2020).

Covid-19 has had an impact on the current economic sector, starting from workers being laid off, PMI Manufacturing Indonesia decreased by 45.3 percent, imports in the first quarter fell 3.7 percent, Inflation, flights at 15 airports were canceled, the decline in tourists to Indonesia, the high losses in the air service sector and the loss of steady income for people with middle to lower status (Hanoatubun, 2020).

The most severe form of the impact of Covid-19 on the economy is employees being laid off and various companies are even threatened with bankruptcy. Data from the Ministry of Labour noted that as many as 114,340 companies had laid off and laid-off workers with a total of $1,943,916$ workers affected by companies with a percentage of $77 \%$ from the formal sector and 23\% from the informal sector (Kemnaker, 2020).

Covid-19 has been a pandemic for more than a year in the world, with various impacts ranging from social, economic, and health problems. Each country has made policies to cope with all the impacts caused by the Covid-19 pandemic, travel restrictions, national quarantines, to entry bans for foreigners are options to be able to anticipate the spread of the virus in their country. This condition causes the economy in every country to experience problems, a decline in public income, inflation, and a recession in the national economy. This impact has been predicted by International Monetary and the World Bank, they say that a global economic recession will occur in the first quarter of 2020 and will enter a recession that is corrected very sharply, and has an impact on the economy of every country. (Nasution, 2020).

Indonesia as one of the developing countries in Southeast Asia is also affected by the global recession as a result of the Covid-19 pandemic. Several steps and efforts have been taken by the government to control the pace of development of Covid-19, reduce economic activity, such as implementing national social restrictions, major social restrictions in every province, and imposing a curfew to reduce people's activities outside the home. The choice was taken to avoid a national quarantine or lockdown like some other countries have done. The government's decision received an award from the world health organization (WHO) for the success of carrying out an Intra Action Review (IAR) against the Covid-19 outbreak. However, the problem of the pandemic does not stop there, as the fourth-largest country by calculating 


\section{Tasharruf: Journal Economics and Business of Islam Vol. 6, No. 1 (2021):1-19 Website: http://journal.iain-manado.ac.id/index.php/TJEBI/index ISSN 2528-0325 (online) ISSN 2528-0317 (print)}

the population of this pandemic can increase the poverty rate, this is bad news if it cannot be controlled by the government.

This social restriction policy certainly has implications for the economic life of the community, especially for the lower middle class, who rely on daily wages to continue their family life. The number of unemployment and poverty will increase because of the social restriction policy, casual workers who usually work and are given daily wages such as in markets, streets, and public places begin to lose income, because of the restrictive policies issued by the government. As a developing country, Indonesia is certainly obliged to pay attention to the poverty rate which is the main point of state development. Based on statistical data in March 2020, it is known that the number of poor people in Indonesia increased by 1.63 million people to 26.42 million people compared to September 2019 data of 24.79 million people (National BPS Data 2020). This shows that the pandemic situation has had a major impact on the economy of the community, especially the lower middle class.

Those who were directly affected by this pandemic began to protest against government policies because they were considered to have harmed and impoverished them economically. This untrue information (hoax) also attacked medical personnel and hospitals handling Covid19, causing public distrust of medical personnel and hospitals, several cases of forced retrieval of PDP and Corona Positive bodies in Manado city became clear evidence that people are starting to lose their trust. against Covid-19 in hospitals.

The work restriction policy carried out by the government has made several companies take policies to lay off some of their employees/ laborers on the grounds of the pandemic and unhealthy company finances due to the direct impact of the pandemic. This makes some employees/ laborers have to return to being unemployed due to being laid off, so they have to try to find other businesses during the pandemic. However, the government, in this case, the central and regional governments, is not silent in finding solutions for various ways to help them survive, such as launching pre-employment cards for those who have experienced termination of employment (PHK) at the company, social assistance, village funds, and assistance from the government. provincial government for poor families.

The government's efforts to reduce the economic impact of the pandemic on the poor have not yet met expectations. Poor families in recent months have continued to grow significantly because people's purchasing power has decreased and they have lost their main source of income. Government assistance is also considered unable to cover family life and is considered less targeted, due to inaccurate data collection processes. In some cases, families 


\section{Tasharruf: Journal Economics and Business of Islam Vol. 6, No. 1 (2021):1-19 Website: http://journal.iain-manado.ac.id/index.php/TJEBI/index ISSN 2528-0325 (online) ISSN 2528-0317 (print)}

have even become poor since the pandemic policy was enacted. Poverty and this pandemic have become inextricably linked in developing countries, with daily workers experiencing a decline to the point of losing their jobs and income.

The linkages between poverty and this pandemic is a new problem that must be resolved, in accordance with the wishes of President Jokowi, in his speech, Jokowi stated that public health is the main priority but must not ignore economic sustainability. Social restrictions can be carried out by limiting the movement of the population, but not with goods and services related to the main activities of the economy. Therefore, various parties are trying to contribute suggestions and thoughts regarding the solutions we face together, presidential instructions to involve sociologists, anthropologists, and religious leaders as communication and educational media as real examples of the involvement of various parties to overcome the pandemic, this pandemic is not only business with health workers but it is a multi-dimensional problem that we must solve together.

People throughout Indonesia hope that the pandemic can be over so that economic conditions can return to what they were before the pandemic, this is the hope of all people, especially those who work for daily wages. However, this hope must be carried out with our joint efforts in trying to break the chain of the coronavirus. Learning from several pandemic cases in Indonesia, we can solve them together. The local government through health promotion continues to try to provide guidance related to health protocols such as washing hands, maintaining distance, and wearing masks as preventive measures for the spread of the coronavirus. Not only involving government officials, but also involving several stakeholders to become communication media including religious leaders, community, youth, lsm, and others. From these various stakeholders, we hope that the delivery of information, symptoms, dangers and prevention regarding COVID-19 can be carried out from the bottom up (bottomup).

\section{The Urgency of Zakat in Economic Improvement}

In general, zakat is very useful in social life. Zakat is an effective way to care for the needy (Ezziti, 2020), Zakat can meet the needs of the poor, can minimize economic differences, reduce the number of social problems, crime, prostitution, homeless people, beggars and others. Qardawi (2000) said that one of the goals of zakat for the recipient is to be able to free the recipient from needs, so that they can live in peace. With zakat, it can protect the community (Huda \& et al, 2012). 


\section{Tasharruf: Journal Economics and Business of Islam Vol. 6, No. 1 (2021):1-19 Website: http://journal.iain-manado.ac.id/index.php/TJEBI/index ISSN 2528-0325 (online) ISSN 2528-0317 (print)}

Zakat is one of the Islamic instruments used to distribute income and wealth. Therefore, the existence of zakat such as zakat firah, zakat maal and professional zakat can reduce wealth inequality in Indonesia, besides that zakat can also be used as a mechanism in overcoming poverty that occurs in Indonesia. (Pratama, 2015). Islam is formed with 5 pillars on the main pillars of the religion, and six pillars of faith for all believers whose provisions have been met, so it is obligatory to carry out the pillars of Islam which is the decree of Allah SWT. One of the purposes of implementing the pillars of Islam is the embodiment of the bond between man and his God, Allah SWT. Not only the bond with God, human beings need to maintain a good bond with fellow human beings, so that fellow human beings love each other, help each other, and God also commands human beings to give zakat by dedicating $2.5 \%$ of their wealth. The realization of human bonds with fellow human beings is one of them by giving zakat, rich people are ordered to spend their wealth for people who are deficient in this case can not meet their daily needs, so there is a relationship of helping and loving fellow human beings. Zakat also aims to make Muslims prosperous, close the gap between the rich and the poor, and convince servitude to Allah SWT by carrying out His commands. Zakat is obligatory by Allah and is set as one of the pillars of Islam listed in the hadith of the book Arba'in Nawāwi :

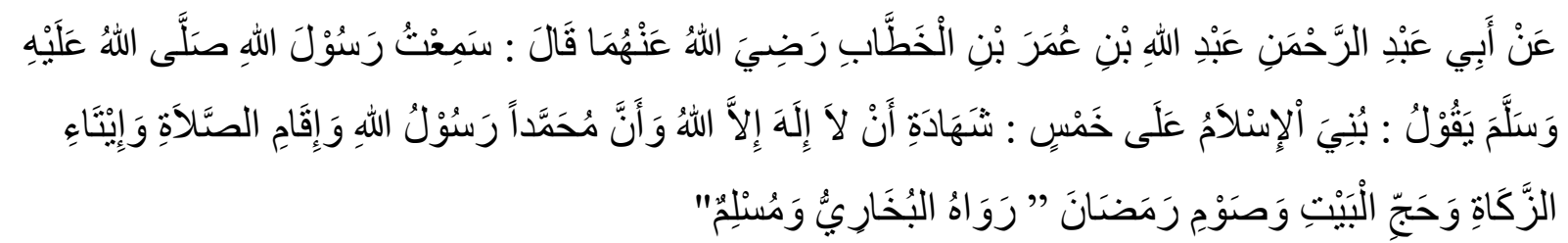

"Abu Abdurrahman Abdullah bin Umar bin Khatab ra said. I once heard the Prophet say: "Islam is built on five pillars, namely the creed that there is no God but Allah and the Prophet Muhammad is His messenger, establish prayers, pay zakat, perform Hajj to the House and fast Ramadan". (HR. Tarmidzi and Muslim).

The position of society is not the same. There are those who get more of God's bounty, there are those who get less, but there are also those who find it difficult to eat every day. One method of closing the gap is zakat. People who are rich in wealth are obliged to spend $2.5 \%$ of their assets because some of the assets we have are other people's rights (M. A. Hasan, 2006). Zakat which is obligatory to be issued from $2.5 \%$ of the wealth of the rich given to those who are entitled to receive zakat (Mustahik) (Anshori, 2006). Al-Qur'an as a guide for Muslims, who are always blessed by Allah SWT. Allah says in the Qur'an in Surah at-Taubah verse 60:

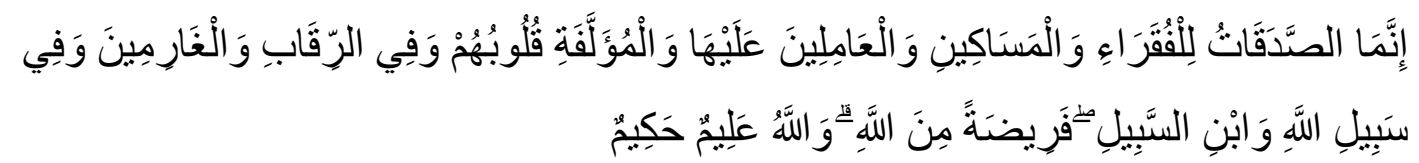




\section{Tasharruf: Journal Economics and Business of Islam Vol. 6, No. 1 (2021):1-19 Website: http://journal.iain-manado.ac.id/index.php/TJEBI/index ISSN 2528-0325 (online) ISSN 2528-0317 (print)}

"Surely the zakat is only for the poor, the needy, amil zakat, whose hearts are softened (converts), to (free) my slaves, to (free) those who are in debt, for the way of Allah and for those who are on a journey, as an obligation from God. Allah is All-Knowing, All-Wise ".

Surah at-Taubah verse 60 commands to give zakat, not only that in this verse also mentions that there are 8 groups who are entitled to receive zakat (Mustahik). The purpose of zakat explained in surah at-Taubah verse 60 is to close the gap that has been explained above, and provide prosperity to Muslims so that zakat is actually given to people who are entitled to receive zakat, namely the 8 groups. In reality, the distribution of zakat is still there that has not been channeled to those who are entitled, because there are still people who are not listed from one of the mustahik zakat, but they receive zakat, One example is among the poor. Poor for $\mathrm{M}$. Quraish Shihab is a working man, but his income has not been able to meet the needs of his life (Shihab, 2000). On the other hand, what happened was when a family issued zakat fitrah which was handed over to the zakat amil in the area, after the distribution of zakat, the family found the zakat share was more than half of the zakat that he issued. However, he should not be one of the poor or poor. Another example, an elderly person, who receives a share of zakat from zakat mal, because that person belongs to a poor group. On the other hand, they are elderly but have rice fields whose results can meet their daily needs and have no dependents. Having children who are already well off and always meet the needs of their parents. While on the other hand there are those who need more encouragement from the zakat, for example for the construction of kindergartens, encouragement for TPQ, and others, which are not mentioned textually in the zakat mustahik circles in the QS. At-Taubah verse 60. On the other hand, for the exegetes, namely Hamka and M. Quraish Shihab, the construction of kindergartens, mosques, and even bridges, is included in one of the 8 groups, namely fisabilillah.

Fisabilillah in the verses of the Qur'an has the meaning of jihad or fighting in the way of Allah. However, there are differences of opinion among commentators on the meaning of fisabilillah, where jihad is defined as a fighter who is involved in war both directly and indirectly who aims to help the religion of God and uphold the word of God. According to other commentators such as al-Maraghi and Hamka means that fisabilillah is all kinds of goodness, obedience, and all social activities. Another opinion defines jihad or war Fisabilillah as a means of goodness that can be pleasing to Allah. While on the social side of jihad or war is meant involvement that is not only in the war against the enemy on the battlefield. However, jihad is in the use of property, intellect, and speech (Idrus, 2011). 


\section{Tasharruf: Journal Economics and Business of Islam Vol. 6, No. 1 (2021):1-19 Website: http://journal.iain-manado.ac.id/index.php/TJEBI/index ISSN 2528-0325 (online) ISSN 2528-0317 (print)}

Zakat issued with a sense of participation between fellow human beings will appear to provide world peace. The Indonesian Zakat Regulation stipulates that Zakat can be used for production purposes to treat the poor and improve their standard of living and social quality (Alim, 2015). In relation to the government's policy regarding preventing the spread of COVID-19 today, in which social distancing, large-scale social restrictions (PSBB), the national quarantine law, quarantine and so on, of course the condition of some Muslims on that day has an impact on economic problems, which of course they really need (Mahmuddin et al., 2020).

Zakat is also a sign of security in the Islamic economic system as a guarantee towards economic stability and continuity of community welfare (Nopiardo, 2015). Then, as a country with the largest Muslim population in the world, Muslims in Indonesia can play their best role in the Islamic economy and finance through various forms or modes of philanthropy, especially during the Covid-19 pandemic (Iskandar et al., 2020). This role is expected to be able to overcome the economic shocks that occur, and the entire community, especially Muslims, can participate and contribute to the recovery of these shocks.

Zakat Fund Accountability can help related parties to be more effective in managing the management of zakat funds (Saad et al., 2014). In UK, the proceeds of zakat management are used to help students pay school fees, help get tickets for each country of origin, or simply for those in need and care for poor children and women (May, 2018).

Zakat plays an important role in reducing the direct and indirect impacts of this Covid19 pandemic. The government, in this case the Minister of Religion (Menag) Fachrul Razi, assesses the role of Zakat during the Covid-19 pandemic is very strategic. Therefore, socialization about Zakat is intensified to help people affected by Covid 19. He said: "Covid19 is a test as well as a driving force to help each other. Zakat currently plays a fundamental role through programs that can help and strengthen society (Sudiana, 2020).

\section{Zakat Distribution Strategy During the Covid 19 Pandemic}

Baznas implements a work plan every year, but during the pandemic, there are more quotas and plans to deal with the Covid-19 pandemic and its impacts. Distribution during the pandemic is hope for people who are struggling financially. With the pandemic, there are many new mustahik as a result of layoffs and the loss of consumers from business actors (Sariyati, 2020).

Baznas as zakat management chart is responsible for the welfare of the Mustahik in accordance with the teachings of Rasulullah SAW (Rachmawati et al., 2019). Therefore, during 


\section{Tasharruf: Journal Economics and Business of Islam Vol. 6, No. 1 (2021):1-19 Website: http://journal.iain-manado.ac.id/index.php/TJEBI/index ISSN 2528-0325 (online) ISSN 2528-0317 (print)}

a pandemic, Baznas continues to distribute Zakat while still implementing health protocols to protect Amil and beneficiaries from contracting the Covid-19 virus. This was conveyed by the Head of Puskas Baznas of the Republic of Indonesia Muhammad Hasbi Zaenal, Ph.D., explaining that there are two types of distribution mechanisms, namely the distribution of Zakat and its use. The distribution is the giving of zakat to mustahik which is a form of short-term consumption. Meanwhile, its use is the best form of zakat utilization without reducing the value of its benefits in the form of a productive business, so that it can benefit effectively. Both distribution mechanisms continue to run by implementing health protocols for the safety of Amil and Mustahik.

Zakat distribution in the form of a production plan can help mustahik have capital in running a business. With a business or business, Mustahik can be independent because he gets income from the business he does. Although it is difficult to make a profit due to the pandemic situation, Mustahik's capital turnover can meet his daily needs.

The distribution of Zakat during the pandemic is adjusted to the conditions and needs of the affected community, such as the provision of masks to prevent the spread of Covid-19 through droplets, which is where liquid or saliva comes out of the nose or mouth when someone sneezes, coughs or even talks. (Mayasiana, 2020). Spraying disinfectant which is one way to prevent the spread of all kinds of viruses or bacteria on the surface of inanimate objects (Nikmah \& Haidarravy, 2020). Provision of APD (Alat Pelindung Diri) or PPE (Personal Protective Equipment) for medical personnel because it is one of the necessities that must be used to protect themselves when in direct contact with patients infected with the Covid19 virus (Andriani et al., 2021). And distribution of family needs in the form of food packages given to families affected by Covid 19.

Baznas distributes zakat periodically which is monitored and evaluated to take corrective action, if activities are found that are not going according to plan (Sariyati, 2020).

\section{The Role of Zakat on Affected Communities}

Zakat aims to overcome social inequality and become a pillar of Islam that improves relations between human beings and strengthens the relationship to Allah as a form of worship. In collecting, distributing and administering zakat, it is the duty of the government, which in this case is managed by Baznas. With the large potential for receiving zakat, the government as the authority holder can force the payment of zakat both to individuals, communities and institutions (Rahman, 2019). The government must intervene in the management of zakat 


\section{Tasharruf: Journal Economics and Business of Islam Vol. 6, No. 1 (2021):1-19 Website: http://journal.iain-manado.ac.id/index.php/TJEBI/index ISSN 2528-0325 (online) ISSN 2528-0317 (print)}

because zakat is a worship that must be carried out by those who have fulfilled the provisions of the Shari'a so that zakat is not a form of generosity without binding provisions.

Zakat is part of the Islamic economic system that covers all aspects of social life, including finance, economy, society, politics, morality, and religion. Zakat aims to achieve socio-economic justice by issuing zakat from aghniya to mustahik (Norvadewi, n.d.). From a financial point of view, the implementation of zakat is carried out in accordance with provisions such as tax payments. Political problems, because the management of zakat is basically carried out by an authorized agency by the government. The moral aspect of zakat can train the human soul to find sympathy among others who are in trouble. The religious aspect of zakat is a form of worship ordained by Allah which is carried out in accordance with the provisions of Islamic law (Hidayatulloh, 2019).

The spread of the Covid-19 pandemic in Indonesia has caused various problems in aspects of people's lives, including the economic aspects in the real sector and the financial sector. The health aspect, where there are emergency medical conditions due to the large number of patients affected by Covid 19. The educational aspect has an impact on teaching and learning activities (KBM) that use online learning methods from home. The religious aspect causes the closure of places of worship, so that religious activity must be carried out in their respective residences. And on the social aspect, there is mutual suspicion between individuals because social distancing is to prevent the spread of Covid-19 (Sariyati, 2020).

The various impacts of Covid 19 that have occurred have been described above, so that the existence of Zakat is very important and is one of the solutions that can overcome the effects of the Covid 19 pandemic. It is very big for the community, especially for Mustahik, so that the existence of Zakat can be a solution to various problems faced by Mustahik.

The difficult conditions during the current pandemic have caused many criminal acts to occur to meet daily needs, especially food needs. Zakat paid by muzakki and distributed by the Amil Agency and Amil Institution will encourage production because mustahik issue Zakat funds to meet their needs in the form of goods and services. With the existence of Zakat, it can enable people to become prosperous in terms of increasing consumption, production and distribution methods. Distributed zakat can increase production due to increased demand (Atabik, 2015).

The Amil Zakat Agency and the Amil Zakat Institution continue to provide various services to facilitate muzakki, hypocrites, and mutashadiq in paying Zakat, especially during a pandemic that limits various activities and requires them to keep their distance from one 


\section{Tasharruf: Journal Economics and Business of Islam Vol. 6, No. 1 (2021):1-19 \\ Website: http://journal.iain-manado.ac.id/index.php/TJEBI/index ISSN 2528-0325 (online) ISSN 2528-0317 (print)}

another. This is in line with the explanation given by the Head of Puskas Baznas Muhammad Hasbi that Baznas, which is a zakat distribution institution, aims to collect and distribute zakat nationally. Therefore, during the pandemic the Zakat Agency and the Zakat Institution continued to pay attention to the development of the Zakat Collection method that remained in accordance with Islamic law. In the current pandemic, Zakat collection is done online to reduce Zakat payments made offline (face to face). Online Zakat payments can be made through various channels including e-commerce, Apps, and social media.

\section{Distribution of Zakat in the Perspective of Maqashid Syariah}

Maqashid Syariah is an idea in Islamic law with the aim of benefiting mankind and preventing the danger. Maqashid Syariah Law aims to protect religion, soul, thought, lineage and property in all human activities (Muchlis, Saiful, 2016). Maqashid Syariah is a Syariah system that aims to create the value of syariah teachings in order to achieve happiness in this world and in the hereafter (Hadidtya et al., 2019).

The purpose of Maqashid Sharia is to provide benefits to mankind in this world and in the hereafter. By maintaining the five basic needs of human life, namely religion, soul, mind, lineage, and property (Mingka, 2015).

The distribution of Zakat carried out by the Zakat Institution during the pandemic is as follows:

1. Distribution of Zakat on the health aspect which is distributed in various programs.

In the distribution of the Baznas Covid-19 handling program, the zakat funds allocated to the health emergency program amounted to Rp. 11.291 .380 .426 or $\mathrm{Rp} .26 \%$ of the total distributed zakat funds of Rp. 43.988.574.774. The distribution of the National OPZ Covid-19 pandemic handling program, the funds allocated for the health emergency program are Rp. 83.022.906.165 or $13 \%$ of the total Rp. 636.895 .452 .954

The funds invested by Baznas in responding to the Covid-19 pandemic were allocated to the procurement of medical equipment for referral hospitals for Covid-19 patients. This is done to protect the public from exposure to the Covid-19 virus.

2. Distribution of Zakat on the aspect of assets distributed in various programs

Protecting property is important in human life. This encourages the community to be involved in economic activities regulated by the Muamalah law. Where, Islam allows humans to look for good treasures and stay away from looking for unlawful treasures.

The distribution of Zakat funds in the socio-economic emergency program is Rp. 30.807.804.156 or $70 \%$ of the total disbursed funds of Rp. 43.988.574.774 Meanwhile, for 


\section{Tasharruf: Journal Economics and Business of Islam Vol. 6, No. 1 (2021):1-19 Website: http://journal.iain-manado.ac.id/index.php/TJEBI/index ISSN 2528-0325 (online) ISSN 2528-0317 (print)}

distribution in handling the Covid 19 pandemic, the National OPZ allocated in the national socio-economic emergency program amounted to Rp. 274.823 .784 .262 or $43.2 \%$ of the total disbursed funds of Rp. 636.895.452.954 Distribution of Zakat funds during the pandemic can help the people of Indonesia to meet their food needs. Thus, the program carried out by Baznas can be a solution for mustahik for economic survival.

3. Distribution of Zakat on the educational aspect which is distributed in various programs

One of the efforts that can be made to provide knowledge to the wider community about steps to prevent the spread of Covid-19 is through the provision of online education. With online education, it can support the formal learning process through the use of technology (Bower, 2019)

The provision of education to the community from early childhood to the elderly carried out by the National Zakat Management Organization (OPZ) of Baznas spent Rp. 1.710.000.000. This educational program is carried out with the aim of increasing knowledge and skills to the community during the pandemic.

4. Distribution of Zakat on religious aspects distributed in various programs

During the Covid-19 pandemic, the obligation to carry out worship must still be carried out in accordance with the health protocols that apply to places of worship. In addition to paying attention to the implementation of worship, fulfill religious obligations by providing services for those who died, especially for those who died due to Covid-19.

The National OPZ Baznas Program distributes zakat funds in the amount of Rp. 77.955.070.000 which is allocated to several programs including funeral services of Rp. 77.460.000.000 with the number of victims are 275, the action of washing mosque carpets Rp. 441.840 .000 carried out on 35 locations, and the distribution of 500 pcs of the total distributed zakat funds of Rp. 53.230.000. 
Tasharruf: Journal Economics and Business of Islam Vol. 6, No. 1 (2021):1-19

Website: http://journal.iain-manado.ac.id/index.php/TJEBI/index ISSN 2528-0325 (online) ISSN 2528-0317 (print)

Table 1. Distribution of Zakat on The Health Aspect Distributed in Various

Programs

\begin{tabular}{|c|c|c|}
\hline No. & Program Name & Quantity \\
\hline 1 & Spraying Disinfectant & 364 Points \\
\hline 2 & Providing Handsanitizer & 25.648bottles \\
\hline 3 & Providing Masks & $35.578 \mathrm{pcs}$ \\
\hline 4 & Making Healthy Washbasins & 113 Points \\
\hline 5 & Health Services & 6.078 People \\
\hline 6 & Ambulance Standby & 13 Units \\
\hline 7 & Providing PPE & 32.039 Packages \\
\hline 8 & Ventilator and X-Ray & 2 Units \\
\hline 9 & Isolation Rooms Obseravasi & 6 Units \\
\hline 10 & $\begin{array}{ll}\text { Hospital Support: } \\
\text { - } \quad 67.465 \text { pcs Medical Masks } \\
\text { - } \quad 2.002 \text { pcs N95 Masks } \\
\text { - } \quad 200.650 \text { Glove Sensi } \\
\text { - } \quad 3385 \text { Pcs Hazmat } \\
\text { - } \quad 10.005 \text { Pcs Cup Head } \\
\text { - } \quad 2.065 \text { Pcs Google Glasses } \\
\text { - } \quad 2.061 \text { Boot } \\
\text { - } \quad 8.000 \text { Cover Shoes } \\
\text { - } \quad 900 \text { Cloth-Mask } \\
\text { - } \quad 635 \text { pcs Surgery Clothes } \\
\text { - } \quad 230 \text { pcs Oka Clothes } \\
\text { - } \quad 4600 \text { Strip Vitamin } \\
\text { - } \quad 60 \text { pcs Face Shield } \\
\end{array}$ & $\begin{array}{l}87 \text { Locations (Hospitals and } \\
\text { Health Centers) }\end{array}$ \\
\hline 11 & Responsive Covid-19 Villages & 70 Villages \\
\hline
\end{tabular}

Source: http://covid19.baznas.go.id/ 
Tasharruf: Journal Economics and Business of Islam Vol. 6, No. 1 (2021):1-19

Website: http://journal.iain-manado.ac.id/index.php/TJEBI/index ISSN 2528-0325 (online) ISSN 2528-0317 (print)

Table 2. Distribution of Zakat on The Aspect of Assets Distributed in Various

Programs

\begin{tabular}{|c|l|l|}
\hline No. & \multicolumn{1}{|c|}{ Program Name } & \multicolumn{1}{c|}{ Total } \\
\hline 1 & Fast Food Delivery Service & 34.982 Portions \\
\hline 2 & Cash for Work & 3.311 People \\
\hline 3 & Family Logistics Packages & 23.652 Packages \\
\hline 4 & Mustahik Cash Assistance (BTM) & $28.312 \mathrm{KK}$ \\
\hline 5 & Direct Cash Assistance (BPKH) & $36.581 \mathrm{KK}$ \\
\hline 6 & Public Kitchens & 3.060 Portions \\
\hline 7 & Shopee Rice & $200.000 \mathrm{Kg}(111$ Distribution Points) \\
\hline 8 & Zakat Fitrah & $89.398 \mathrm{KK}(220$ Distribution Points) \\
\hline 9 & Giving Fruits & $\begin{array}{l}\text { Oranges: } 235 \mathrm{Kg} \\
\text { Guava: } 225 \mathrm{Kg}\end{array}$ \\
\hline
\end{tabular}

Source: http://covid19.baznas.go.id/

Table 3. Distribution of Zakat on The Educational Aspect Distributed in Various

Programs

\begin{tabular}{|c|l|l|}
\hline No. & \multicolumn{1}{|c|}{ Program Name } & \multicolumn{1}{|c|}{ Total } \\
\hline 1 & Online Education & Daily \\
\hline 2 & Strengthening of Radio-based Communication Tools & 4 Units \\
\hline 3 & Community Education & 244 locations \\
\hline
\end{tabular}

Source: http://covid19.baznas.go.id/

Table 4. Distribution of Zakat on Religious Aspects Distributed in Various Programs

\begin{tabular}{|c|l|l|}
\hline No. & \multicolumn{1}{|c|}{ Program Name } & \multicolumn{1}{|c|}{ Total } \\
\hline 1 & Corpse Service & 275 Souls \\
\hline 2 & Actions to Washing Mosque Carpets & 35 Locations \\
\hline 3 & Distribution of Prayer Mats & 500 Pcs \\
\hline
\end{tabular}

Source: http://covid19.baznas.go.id/ 


\section{Tasharruf: Journal Economics and Business of Islam Vol. 6, No. 1 (2021):1-19 \\ Website: http://journal.iain-manado.ac.id/index.php/TJEBI/index ISSN 2528-0325 (online) ISSN 2528-0317 (print)}

Sustainability of the Existing Program is that zakat distribution programs that have been running by targeting Mustahik can always be continuous so that the impact of Covid-19 on Mustahik who has been fostered by BAZNAS can be minimized. In this program, Baznas distributed funds of Rp. 1.889.390.192 or about 4\% of the total disbursed funds Rp. 43.988.547.774 of the total mustahik beneficiaries of 427.198 (Baznas data as of July 20, 2020). Meanwhile, the distribution of the handling of the Covid 19 pandemic carried out by the National OPZ in the existing program has distributed funds with a total of $\mathrm{Rp}$. 279.048.762.527 or around $43.8 \%$ of the total funds of Rp. 636.895.452.952 to a total of 5.177.390 beneficiaries (Sariyati, 2020). The number of beneficiaries of programs distributed by Baznas is expected to increase, possibly reaching 4 to 5 million people. This shows that the role of Zakat is increasingly important and is related to social needs (Pamungkas, Beni Tri, 2021).

\section{CONCLUSION}

Covid-19 has had a comprehensive impact on the social, cultural and economic life of the community. These changes make humans do various ways to adapt in order to survive. Islam has provided various mechanisms in dealing with these changes, one of which is through the zakat mechanism which has been regulated in the Qur'an and Hadith. Therefore, the results of research in this journal show the function of zakat when facing a pandemic. Zakat also aims to prosper Muslims, close the gap between the rich and the poor, and ensure servitude to Allah SWT by carrying out His commands. Zakat is a bulwark of security in the Islamic economic system as a guarantee towards economic stability and continuity of community welfare. As a country with the largest Muslim population in the world, Muslims in Indonesia can play their best role in the Islamic economy and finance through various forms or modes of philanthropy, especially during the Covid-19 pandemic. This role is able to overcome the economic shocks that occur, and the entire community, especially Muslims, can participate and contribute to the recovery of these shocks.

\section{REFERENCES}

Alim, M. N. (2015). Utilization and Accounting of Zakat for Productive Purposes in Indonesia :

A Review. Procedia - Social and Behavioral Sciences, 211, 232-236. https://doi.org/10.1016/j.sbspro.2015.11.028

Andriani, R. N., Tohir, G. A., \& Pramayastri, V. (2021). Evaluasi Kesehatan Kerja Petugas 


\section{Tasharruf: Journal Economics and Business of Islam Vol. 6, No. 1 (2021):1-19 \\ Website: http://journal.iain-manado.ac.id/index.php/TJEBI/index ISSN 2528-0325 (online) ISSN 2528-0317 (print)}

Kesehatan di IGD RSUD Palembang Bari terhadap Wabah Covid-19. OKUPASI:

Scientific Journal of Occupational Safety \& Health, 1(1).

Anshori, A. G. (2006). Hukum dan Pemberdayaan Zakat: Upaya Sinergis Wajib Zakat dan Pajak di Indonesia. Pilar Media.

Atabik, A. (2015). Peranan Zakat dalam Pengentasan Kemiskinan. ZISWAF, 2(2), 339-361.

Azwar. (2020). Solusi Ekonomi dan Keuangan Islam di Masa Pandemi Covid-19. Kemenkeu.Go.Id.

Baldwin, R., \& Weder, B. (2020). Economics in the Time of COVID-19. CEPR Press.

Bank, W. (2020). World Bank Group and COVID-19 (coronavirus). The World Bank IBRDIDA.

Bashir, S., Alabdulkarim, N., Altwaijri, N., Alhaidri, N., Hashim, R., Nasim, E., Mir, A., Albaradie, R., Shahid, S., \& Abualait, T. (2021). The battle against the COVID-19 pandemic- a perspective from Saudi Arabia. One Health, 12(September 2020), 100229. https://doi.org/10.1016/j.onehlt.2021.100229

Bower, M. (2019). Technology-mediated learning theory. British Journal of Educational Technology, 50(3), 1035-1048. https://doi.org/https://doi.org/10.1111/bjet.12771

Ezziti, B. (2020). Zakat as a Means of Social Welfare: Exploring a Recent Fatwa From The Moroccan 'Ulama' on The Permisibility of Paying Zakat in Advance to Help The Poor of The Covid-19. AZKA: International Journal of Zakat \& Social Finance, 1(1), 94-101.

Hadidtya, S., Yafitz, M., \& Nurozi, A. (2019). Implementasi Maqashid Syariah Indeks (MSI) terhadap Kinerja Tenaga Kependidikan FIAI UII. At-Thullab Jurnal Mahasiswa Studi Islam, 1(1), 58-70.

Hanoatubun, S. (2020). Dampak Covid-19 Terhadap Perekonomian Indonesia. EduPsyCouns Journal, 2(1), 146-153.

Hasan, M. A. (2006). Zakat dan Infak. Kencana Prenada Media Group.

Hasan, S. (2007). Zakat Dalam Pusaran Arus Modernitas (H. Syaifuddin (ed.)). UIN Malang Press.

Hidayatulloh, M. H. (2019). Peran Zakat dan Pajak Dalam Menyelesaikan Masalah Perekonomian Indonesia. Al-Huquq: Journal of Indonesian Islamic Economic Law, 1(2), $102-121$.

Huda, N., \& et al. (2012). Keuangan Publik Islam: Pendekatan Teoritis Dan Sejarah, (Jakarta: Prenadamedia Grup, 2012. Prenada Media.

Idrus, J. (2011). Makna Fi Sabilillah dalam Al-Qur'an (Suatu Kajian Tafsir Maudhu'iy). UIN 


\section{Tasharruf: Journal Economics and Business of Islam Vol. 6, No. 1 (2021):1-19 \\ Website: http://journal.iain-manado.ac.id/index.php/TJEBI/index ISSN 2528-0325 (online) ISSN 2528-0317 (print)}

Sultan Syarif Kasim Riau.

Iskandar, A., \& Aqbar, K. (2020). Analisis Kebijakan Penarikan Zakat Umar bin Khattab dan Relevansinya Terhadap Masa Krisis Pandemi Covid-19. SALAM; Jurnal Sosial \& Budaya Syar-I, 7(10), 949-960.

Iskandar, A., Possumah, B. T., \& Aqbar, K. (2020). Peran Ekonomi dan Keuangan Sosial Islam saat Pandemi Covid-19 Peran Ekonomi dan Keuangan Sosial Islam Sekolah Tinggi Ilmu Islam dan Bahasa Arab ( STIBA ), Makassar. SALAM; Jurnal Sosial \& Budaya Syar-I, 7(7), 625-638. https://doi.org/10.15408/sjsbs.v7i7.15544

Kadir, A., Hakim, M. R., Syam, F., \& Karim, M. S. (2020). Penggunaan Dana Zakat pada Korban Covid-19 Perspektif Maqashid Syariah. Al-Tafaqquh: Journal of Islamic Law, $1(2), 107-116$.

Kemnaker, B. H. (2020). Menaker: Badai Pasti Berlalu, Panggil Kembali Pekerja yang terPHK Nanti. Kementerian Keuangan Republik Indonesia.

Mahmuddin, R., Rafi, I., Aqbar, K., \& Iskandar, A. (2020). Hukum Mentegerakan Penyerahan Zakat Harta dan Zakat. BUSTANUL FUQAHA: Jurnal Bidang Hukum Islam, 1(2), 125136.

May, S. (2018). "The Best of Deeds": The Practice of Zakat in the UK. Journal of Church and State, 61(2), 200-221. https://doi.org/10.1093/jcs/csy034

Mayasiana, N. A. (2020). Pelatihan Pembuatan Masker Kain 3 Lapis untuk Pencegahan Covid19. Majalah Ilmiah “PELITA ILMU,” 3(1).

Mingka, A. (2015). Maqashid Syariah dalam Ekonomi, Keuangan dan Perbankan Syariah. Iqtishad Consulting.

Moleong, L. J. (2007). Metodologi Penelitian Kualitatif. PT Remaja Rosdakarya.

Muchlis, Saiful, and A. S. S. (2016). Implementasi Maqashid Syariah dalam Corporate Social Responsibility di PT Bank Muamalat Indonesia. Jurnal Akuntansi Multiparadigma, 7(1), 120-130. https://doi.org/http://dx.doi.org/10.18202/jamal.2016.04.7011

Nasution, D. (2020). Dampak Pandemi Covid-19 Terhadap Perekonomian Indonesia. Jurnal Benefita, 5(2), 212-224.

Nikmah, S., \& Haidarravy, S. (2020). Pembuatan Cairan Desinfektan dan Bilik Disinfektan sebagai Upaya Pencegahan Virus COVID-19di Mlajah Bangkalan Madura. Jurnal Abidas, 1(5).

Nopiardo, W. (2015). Zakat sebagai Ibadah Maliyah Ijtima'iyah dalam Perspektif Ilmu Ekonomi Islam. JURIS, 14(2), 208-224. 


\section{Tasharruf: Journal Economics and Business of Islam Vol. 6, No. 1 (2021):1-19 \\ Website: http://journal.iain-manado.ac.id/index.php/TJEBI/index ISSN 2528-0325 (online) ISSN 2528-0317 (print)}

Norvadewi. (n.d.). Optimalisasi Peran Zakat dalam Mengentaskan Kemiskinan di Indonesia. Pamungkas, Beni Tri, and M. M. (2021). Peranan Organisasi Pengelola Zakat dalam Penanganan Covid-19 di Kabupaten Banyumas. Alhamra: Jurnal Studi Islam, 2(1).

Pratama, Y. C. (2015). Peran Zakat dalam Penanggulangan Kemiskinan (Studi Kasus:

Program Zakat Produktif Pada Badan Amil Zakat Nasional). The Journal of Tauhidinomics, 1(1), 93-104.

Qardawi, Y. (2000). Hukum Zakat: Studi Komparatif Menegnai Status Dan Filsafat Zakat Berdasarkan Qur'an Dan Hadis. PT Pustaka Utera AntarNusa.

Rachmawati, E. N., Azmansyah, A., \& Utami, T. T. (2019). Analisis Zakat Produktif dan Dampaknya Terhadap Pertumbuhan Usaha Mikro dan Penyerapan Tenaga Kerja serta Kesejahteraan Mustahik di Kota Pekanbaru Provinsi Riau. Jurnal Ilmu Manajemen, 8(2), $1-14$.

Rahman, M. R. (2019). Peran Zakat Dalam Mengentaskan Kemiskinan Di Indonesia. Hukum Islam, 19(2), 130-148.

Rizal, F., \& Mukaromah, H. (2021). Filantropi Islam Solusi atas Masalah Kemiskinan Akibat Pandemi Covid-19. Al-Manhaj: Jurnal Hukum Dan Pranata Sosial Islam, 3(1), 35-66.

Saad, R. A. J., Aziz, N. M. A., \& Sawandi, N. (2014). Islamic Accountability Framework in the Zakat Funds Management. Procedia - Social and Behavioral Sciences, 164(August), 508-515. https://doi.org/10.1016/j.sbspro.2014.11.139

Sariyati, B. (2020). Analisis Distribusi Zakat, Infak dan Sedekah dalam Penanggulangan Pandemi Covid-19 Perspektif Maqashid Syariah (Studi Kasus BAZNAS Republik Indonesia). IAIN Salatiga.

Shihab, M. Q. (2000). Tafsir al-Mishbah: Pesan, Kesan, dan Keserasian al-Qur'an. Lentera Hati.

Sudiana, N. (2020). Pendayagunaan Zakat di Era Pandemi Covid-19 (Vol 2). Forum Zakat. 